\title{
Nanotetrac targets integrin $\alpha v \beta 3$ on tumor cells to disorder cell defense pathways and block angiogenesis
}

This article was published in the following Dove Press journal:

OncoTargets and Therapy

18 September 2014

Number of times this article has been viewed

\author{
Paul J Davis ${ }^{1,2}$ \\ Hung-Yun $\operatorname{Lin}^{2,3}$ \\ Thangirala Sudha ${ }^{2}$ \\ Murat Yalcin ${ }^{2,4}$ \\ Heng-Yuan Tang ${ }^{2}$ \\ Aleck Hercbergs ${ }^{5}$ \\ John T Leith ${ }^{6}$ \\ Mary K Luidens' \\ Osnat Ashur-Fabian ${ }^{7,8}$ \\ Sandra Incerpi ${ }^{9}$ \\ Shaker A Mousa ${ }^{2}$ \\ 'Department of Medicine, Albany \\ Medical College, Albany, NY, USA; \\ 2Pharmaceutical Research Institute, \\ Albany College of Pharmacy and \\ Health Sciences, Albany, NY, USA; \\ ${ }^{3} \mathrm{PhD}$ Program for Cancer Biology \\ and Drug Discovery, College of \\ Medical Science and Technology, Taipei \\ Medical University, Taipei, Taiwan; \\ ${ }^{4}$ Department of Physiology, Veterinary \\ Medicine Faculty, Uludag University, \\ Gorukle, Bursa, Turkey; ${ }^{5}$ Radiation \\ Oncology, Cleveland Clinic, Cleveland, \\ $\mathrm{OH}, \mathrm{USA} ;{ }^{6}$ Rhode Island Nuclear \\ Science Center, Narragansett, RI, \\ USA; ${ }^{7}$ Translational Hemato-oncology \\ Laboratory, Hematology Institute \\ and Blood Bank, Meir Medical Center, \\ Kfar-Saba, Israel; ${ }^{8}$ Department of \\ Human Molecular Genetics and \\ Biochemistry, Sackler Faculty of \\ Medicine, Tel Aviv University, Tel \\ Aviv, Israel; ' ${ }^{2}$ Department of Sciences, \\ University of Roma Tre, Rome, Italy
}

Correspondence: Paul J Davis Pharmaceutical Research Institute, One Discovery Drive, Rensselaer, NY 12 | 44, USA

Tel + I 5184287848

Fax + I 5186947567

Email pdavis.ordwayst@gmail.com

\begin{abstract}
The extracellular domain of integrin $\alpha v \beta 3$ contains a receptor for thyroid hormone and hormone analogs. The integrin is amply expressed by tumor cells and dividing blood vessel cells. The proangiogenic properties of thyroid hormone and the capacity of the hormone to promote cancer cell proliferation are functions regulated nongenomically by the hormone receptor on $\alpha v \beta 3$. An L-thyroxine $\left(\mathrm{T}_{4}\right)$ analog, tetraiodothyroacetic acid (tetrac), blocks binding of $\mathrm{T}_{4}$ and 3,5,3'-triiodo-L-thyronine $\left(\mathrm{T}_{3}\right)$ by $\alpha v \beta 3$ and inhibits angiogenic activity of thyroid hormone. Covalently bound to a $200 \mathrm{~nm}$ nanoparticle that limits its activity to the cell exterior, tetrac reformulated as Nanotetrac has additional effects mediated by $\alpha v \beta 3$ beyond the inhibition of binding of $\mathrm{T}_{4}$ and $\mathrm{T}_{3}$ to the integrin. These actions of Nanotetrac include disruption of transcription of cell survival pathway genes, promotion of apoptosis by multiple mechanisms, and interruption of repair of double-strand deoxyribonucleic acid breaks caused by irradiation of cells. Among the genes whose expression is suppressed by Nanotetrac are EGFR, VEGFA, multiple cyclins, catenins, and multiple cytokines. Nanotetrac has been effective as a chemotherapeutic agent in preclinical studies of human cancer xenografts. The low concentrations of $\alpha v \beta 3$ on the surface of quiescent nonmalignant cells have minimized toxicity of the agent in animal studies.
\end{abstract}

Keywords: integrin, thyroid hormone, thyroxine, antiangiogenesis, proapoptosis

\section{Introduction}

A number of in vitro and in vivo studies have supported a role for thyroid hormone in the proliferation of tumor cells. ${ }^{1-7}$ Thyroid hormone is proangiogenic, ${ }^{8-11}$ and this property may be relevant to tumor biology. ${ }^{12,13}$ Clinical evidence of thyroid hormone dependence of cancers has come from studies of glioblastoma, ${ }^{14}$ breast cancer, ${ }^{15}$ and tyrosine kinase inhibitor-treated renal cell carcinoma, ${ }^{16}$ and head and neck cancers. ${ }^{17}$ Such studies have been reviewed by Hercbergs et al. ${ }^{18}$

In 2005, we described a receptor for thyroid hormone on plasma membrane integrin $\alpha v \beta 3$ that regulated angiogenesis. ${ }^{9}$ Of the more than 20 plasma membrane integrins, only $\alpha v \beta 3$ binds thyroid hormone and hormone analogs such as tetraiodothyroacetic acid (tetrac). ${ }^{9}$ The ectodomains of integrins contain a variety of binding sites for extracellular matrix proteins. ${ }^{19}$ On integrin $\alpha v \beta 3$, however, there are also discrete small molecule receptors for resveratrol ${ }^{20}$ and androgen, ${ }^{21}$ as well as for thyroid hormone. The intracellular domain of the integrin activates signaling pathways that relate to specific gene transcription ${ }^{22}$ and interacts with the cytoskeleton. ${ }^{23}$ The nongenomic regulation of the state of the actin cytoskeleton by L-thyroxine $\left(\mathrm{T}_{4}\right)$ described by Leonard and Farwell ${ }^{24}$ and Farwell et $\mathrm{al}^{25}$ may be mediated by $\alpha v \beta 3$ (see the Angiogenesis modulation by thyroid hormone and tetrac formulations section). 
The thyroid hormone receptor on the integrin mediates the actions of the hormone on tumor cell proliferation ${ }^{5-7,12,26}$ and on angiogenesis. ${ }^{8,9}, 12,13$ We discuss in this review the significance of the interface of thyroid hormone and cancer cells at integrin $\alpha v \beta 3$, interpreted in part by the actions of the deaminated analog of $\mathrm{T}_{4}$, tetrac, and its nanoparticulate formulation as antithyroid agents at the integrin. In this formulation, tetrac is covalently bound to poly(lactic-coglycolic acid) and thus is excluded from the cell interior. ${ }^{11}$ Acting exclusively at the integrin, Nanotetrac does block the proliferative and proangiogenic effects of $\mathrm{T}_{4}$ and 3,5, ${ }^{\prime}$-triiodo-L-thyronine $\left(\mathrm{T}_{3}\right)$ initiated at the cell surface. However, the compound also has effects via the integrin on transcription of genes integral to cancer cell survival pathways, and these effects appear unrelated to agonist $\mathrm{T}_{4}$ and $T_{3}$. The integrin also mediates antiangiogenic actions of Nanotetrac that are independent of $\mathrm{T}_{4}$ and $\mathrm{T}_{3}$. The nanoparticulate drug does not affect genomic actions of thyroid hormone within the cell that depend primarily upon nuclear receptor (TR) $-\mathrm{T}_{3}$ complex formation ${ }^{27}$ or interactions of $\mathrm{T}_{3}$ with mitochondria. ${ }^{28}$

\section{Thyroid hormone-tetrac receptor on integrin $\alpha v \beta 3$}

The thyroid hormone-tetrac binding site on the integrin includes contributions from both $\alpha \mathrm{v}$ and $\beta 3$ monomers. ${ }^{29}$ The site accommodates $\mathrm{T}_{4}, \mathrm{~T}_{3}$, tetrac, and other hormone analogs such as diiodothyropropionic acid. ${ }^{30}$ The affinity of the receptor is higher for $\mathrm{T}_{4}$ than for $\mathrm{T}_{3},{ }^{9}$ and binding of $\mathrm{T}_{4}$ occurs at physiological levels of free $\mathrm{T}_{4}$. The significance of this is that circulating $\mathrm{T}_{4}$ supports tumor cell proliferation in the intact organism.

The receptor is subspecialized. One domain that controls cell proliferation binds both $\mathrm{T}_{4}$ and $\mathrm{T}_{3}$ and activates the mitogen-activated protein kinase (ERK1/2) signal transduction pathway. ${ }^{31}$ This area of the receptor is involved in stimulation of cell proliferation. The second domain binds only $\mathrm{T}_{3}$ and activates the phosphatidylinositol 3-kinase pathway. Downstream consequences of such activity include nuclear uptake of TR $\alpha$ resident in cytoplasm and expression of the hypoxia-inducible factor- $1 \alpha(H I F-1 \alpha)$ gene. ${ }^{31}$ Tetrac blocks hormone actions initiated at both domains.

\section{Angiogenesis modulation by thyroid hormone and tetrac formulations}

The proangiogenic activity of thyroid hormone - and the antiangiogenic properties of tetrac - which begins at $\alpha v \beta 3$, appears to involve several mechanisms. For example, the integrin is known to interact physically with the vascular endothelial growth factor (VEGF) receptor family that is adjacent to $\alpha v \beta 3$ molecules. ${ }^{32}$ In the absence of $\mathrm{T}_{4}$ and $\mathrm{T}_{3}$, tetrac and Nanotetrac block activity of VEGF and basic fibroblast growth factor (bFGF) in the chick chorioallantoic membrane angiogenesis assay, ${ }^{33}$ presumptively by disrupting crosstalk between the integrin and VEGF receptor and bFGF receptor. However, tetrac can also decrease $b F G F$ gene transcription and decrease bFGF protein release by cells. ${ }^{8}$ Agonist thyroid hormone enhances platelet-derived growth factor activity (Mousa, unpublished observations), and this effect is subject to tetrac inhibition. Epidermal growth factor (EGF) is also proangiogenic, and Nanotetrac, acting via $\alpha v \beta 3$, downregulates transcription of the EGFR gene. ${ }^{12}$ Thus, a number of molecular mechanisms are involved in actions of thyroid hormone analogs at their receptor on the integrin. Other tumor cell genes affected by Nanotetrac via $\alpha v \beta 3$ are discussed here.

Beyond vascular growth factor gene expression and vascular growth receptor function, there are additional contributions to angiogenesis that originate at the thyroid hormone receptor on the integrin. Endothelial cell migration is regulated by $\mathrm{T}_{4}$ at $\alpha \mathrm{v} \beta 3$ and blocked by tetrac, ${ }^{34}$ as is fibroblast motility. The integrity of the actin cytoskeleton depends upon $\mathrm{T}_{4}$ - conversion of soluble actin to fibrous actin by a nongenomic mechanism ${ }^{24,25}$ - and cell motility and integrin function depend upon the state of the cytoskeleton. Leonard and Farwel1 ${ }^{24}$ have also shown that cell attachment to laminin is $\mathrm{T}_{4}$-requiring and integrin-dependent. We propose that the actions of $\mathrm{T}_{4}$ on the state of actin and cell-laminin interactions may be initiated at $\alpha v \beta 3$. Integrin clustering in response to binding of Arg-Gly-Asp peptides promotes actin polymerization. ${ }^{35}$ The laminin effect of the hormone is impaired by blockade of recognition sites for such peptides on the integrin. Blockade of such sites can inhibit certain of the actions of iodothyronines at their receptor on the integrin. ${ }^{31}$

Small arteriole muscularization is promoted by thyroid hormone, ${ }^{36}$ but it is not yet known whether this effect is $\alpha v \beta 3$ dependent. Tetrac decreases abundance of angiopoietin-2 (Ang-2) messenger ribonucleic acid (mRNA) in endothelial cells ${ }^{33}$ but does not affect Ang-1. Ang-2 protein destabilizes blood vessel structure in anticipation of vascular growth factor action and promotion of angiogenesis, whereas Ang-1 stabilizes such structure and functionally is antiangiogenic.

The distribution of the integrin among various types of cells is relevant to therapeutic exploitation of the small molecule receptors on $\alpha v \beta 3$, such as those for thyroid hormone. Rapidly dividing cells, notably cancer cells and endothelial 
cells about tumors, express the integrin generously. Nonmalignant, quiescent cells do not. When we examined immortalized noncancer human and nonhuman primate cells for susceptibility to antiproliferative action of Nanotetrac, we found no drug activity (Mousa, unpublished observations).

\section{Tumor cell genes whose transcription is regulated by the thyroid hormone-tetrac receptor on integrin $\alpha v \beta 3$}

We have identified more than 40 genes in human cancer cells that are regulated from $\alpha v \beta 3$ by Nanotetrac. ${ }^{12,37,38}$ Certain of these genes are presented in Table 1, with the data drawn from studies of MDA-MB-231 breast cancer cells ${ }^{37}$ and medullary thyroid carcinoma cells. ${ }^{38}$ What is remarkable is the coherence of the up- or downregulation of these genes. For example, transcription of proapoptosis genes is increased by Nanotetrac - CASP2, CASP8AP2, BCL2L14, DFFA - and antiapoptotic XIAP expression is decreased. Twenty-one of 23 protooncogenes are downregulated, as are eight of nine cyclin genes that are critical to cell cycle regulation and a cyclin-dependent kinase. All of these drug effects are consistent with a desirable multitarget chemotherapeutic profile. It should also be noted that tetrac/Nanotetrac promotes accumulation of proapoptotic Bcl- $\mathrm{X}_{\mathrm{S}}$ mRNA but does not affect Bcl- $\mathrm{X}_{\mathrm{L}} \cdot{ }^{39}$

Table I Representative tumor cell genes whose expression is differentially modulated by Nanotetrac (nanopartiuclate tetrac)

\begin{tabular}{ll}
\hline Function/gene & Up- or downregulation \\
\hline Cell cycle & \\
Cyclins & $\downarrow$ \\
CDKN2C & $\uparrow$ cyclin-dependent kinase inhibitor \\
Proapoptosis & $\uparrow$ \\
CASP2 & $\uparrow$ \\
CAP8AP2 & $\uparrow$ DNA fragmentation factor subunit alpha \\
DFFA & $\uparrow$ \\
BCL2LI4 & \\
Antiapoptosis & $\downarrow$ X-linked inhibitor of apoptosis protein \\
XIAP & $\downarrow$ \\
Wnt-catenin pathway & $\downarrow$ \\
CTNNAI & $\downarrow$ \\
CTNNA2 & $\uparrow$ nuclear inhibitor of catenin \\
CBYI & \\
Antiangiogenesis & \\
TSPI & $\downarrow$ \\
Vascular growth factors & \\
VEGFA & $\downarrow$ \\
bFGF & $\downarrow$ \\
Growth factor receptors & \\
EGFR & $\downarrow$ \\
\hline
\end{tabular}

The complex actions of Nanotetrac on angiogenesis have been mentioned previously, and EGFR was included in this context. EGF is mitogenic and its receptor mediates other tumor cell support functions beyond angiogenesis. These have made the receptor, EGFR, and its ligand, EGF, chemotherapeutic targets, ${ }^{40}$ and cetuximab is the prototypical clinical EGFR antibody. The action of Nanotetrac to suppress transcription of the EGF receptor gene conceptually has advantages over EGFR antibody because Nanotetrac is targeted to cancer cells that express $\alpha v \beta 3$ and thus does not affect this cell surface target in healthy (nonmalignant) cells. In addition, Nanotetrac has a spectrum of other anticancer actions noted previously.

One of the unique attributes of the tetrac receptor on integrin $\alpha v \beta 3$ is that it is linked to the thrombospondin 1 (TSP1; THBS1) gene. Expression of this gene is almost invariably suppressed in tumor cells, since the gene product is an endogenous antiangiogenic factor. Nanotetrac causes transcription of TSP1, and this is one of a number of antiangiogenic mechanisms activated by the drug. Another important function of the TSP1 protein is that it is a ligand of CD47. ${ }^{41}$ CD47 is a cell surface antigen that, expressed by cancer cells, limits antitumor immunity - producing the "Do not eat me" state - and immune system-mediated phagocytosis/ destruction. ${ }^{42}$ Antibodies to CD47 are being tested for utility as anticancer agents that promote host immune system attack on cancer cells. Bound to CD47, TSP1 released in response to Nanotetrac may achieve the same chemotherapeutic outcome as anti-CD47. ${ }^{41}$

Rae et $\mathrm{al}^{43}$ have shown that matrix metalloproteinase-9 $(M M P-9)$ gene expression is increased by thyroid hormone in ovarian cells. Ashur-Fabian has confirmed that $\mathrm{T}_{4}$ causes transcription of MMP-9 in myeloma cells and has found that tetrac blocks this effect (Cohen, Flint, Shalev, and AshurFabian, unpublished observations). Thus, $\alpha v \beta 3$ is involved in this effect on $M M P-9$. The significance of the effect is that MMPs act on cell-cell interaction and cell-matrix adhesion proteins, destabilizing tissues and promoting tumor cell invasiveness and metastasis. ${ }^{44}$

Finally, agonist thyroid hormone induces internalization of $\alpha v \beta 3 .{ }^{45}$ This was initially interpreted by us to reflect the known recycling of the integrin ${ }^{46}$ but is now recognized to be relevant to gene expression. Tetrac blocked internalization of $\alpha v \beta 3$, and we subsequently found that $\mathrm{T}_{4}$ directed the $\alpha \mathrm{v}$ monomer, but not $\beta 3$, into the cell nucleus. In the nucleus, $\alpha v$ was found to function as a coactivator, supporting transcription of several genes that are important to cancer cell biology, including $H I F-1 \alpha$ and the estrogen 
receptor $(E R \alpha) .{ }^{45}$ Thus, the thyroid hormone-tetrac receptor on $\alpha v \beta 3$ has a variety of functions mediated by the intact heterodimer, but the interaction of hormone and $\alpha v \beta 3$ is capable of changing the structure and function of the integrin.

\section{Radiosensitization induced by tetrac formulations}

Nanotetrac and tetrac induce radiosensitization of cancer cells via the $\alpha v \beta 3$ receptor for thyroid hormone. ${ }^{47,48}$ Our studies of this action disclosed a remarkable behavior of the integrin when tumor cells are subjected to radiation - namely, an acute and substantial increase in the number of active ("open conformation") $\alpha v \beta 3$ molecules in the plasma membrane. ${ }^{49}$ We interpret this as a defensive response. Nanotetrac blocks this radiation response. The $\alpha v \beta 3$-dependent radiosensitization process is also associated with a tetrac-induced loss of capacity of tumor cells to repair double-stranded deoxyribonucleic acid breaks caused by radiation. ${ }^{48}$

\section{Discussion}

In the course of describing certain novel cellular actions of $\mathrm{T}_{4}$ and $\mathrm{T}_{3}$, we determined that these actions could be reproduced by agarose- $\mathrm{T}_{4}$, a nanoparticulate formulation of the hormone that cannot enter the cell., ${ }^{8,50,51}$ Thus, the actions were necessarily initiated at the plasma membrane and were nongenomic in mechanism. We also found that tetrac, the naturally occurring deaminated metabolic product of $\mathrm{T}_{4}$, inhibited these membrane-initiated actions of iodothyronines and agarose- $\mathrm{T}_{4} \cdot{ }^{50,51}$ We described the plasma membrane receptor for thyroid hormone on integrin $\alpha v \beta 3$ a decade ago $^{9}$ and distinguished the downstream consequences and mechanisms of nongenomic actions initiated at the integrin from genomic actions. ${ }^{12,27}$ We confirmed the activity of tetrac as an inhibitor of nongenomic actions of $\mathrm{T}_{4}$ and $\mathrm{T}_{3}$ at the hormone receptor on $\alpha v \beta 3 .{ }^{9,12}$ Reformulation of tetrac as Nanotetrac ${ }^{38,52}$ resulted in an agent that is limited to the extracellular space and that is a more potent inhibitor of agonist thyroid hormone actions. ${ }^{12}$ In addition, as pointed out, Nanotetrac modulates expression of a broader spectrum of cancer cell survival pathway genes.

Nanotetrac has an attractive set of properties as an anticancer and antiangiogenic agent. ${ }^{12}$ The $\alpha v \beta 3$ integrin that contains the specific target of Nanotetrac is expressed by, or activated primarily on, cancer cells and supporting blood vessels about tumors. This limits the risk of exposure of nonmalignant cells to the drug. The drug is limited to the extracellular space, and this prevents undesirable effects of unmodified tetrac inside normal cells. Nanotetrac does not inactivate $\alpha v \beta 3$, as antibody to the integrin may, but selectively manipulates the functions of the integrin, so that apoptosis is fostered and antiapoptosis defenses are disordered. Desirable features of Nanotetrac action that were unexpected are enhanced transcription of antiangiogenic TSP1 and decreased expression of EGFR, of matrix metalloproteinases ${ }^{43}$ that support tumor aggressiveness, and of cyclins and protooncogenes. ${ }^{12,45}$ Finally, the agent has a complex set of antiangiogenic properties. As noted previously, these include decreasing transcription of genes coding for vascular growth factors and blunting the activity of these factors at their specific receptors adjacent to the integrin on the cell surface. ${ }^{13,51}$

The poly(lactic-co-glycolic acid) nanoparticle to which tetrac is covalently bound in Nanotetrac is capable of adsorbing traditional nonprotein cancer chemotherapeutic agents. The targeting by tetrac of the nanoparticulate to cancer cells permits local delivery of such second agents, an approach that is more desirable than systemic administration of the drugs.

\section{Acknowledgment}

The support of M Frank Rudy, Margaret D Rudy, and Richard Liebich was essential to a number of the experiments reviewed in this paper.

\section{Disclosure}

Authors PJ Davis and SA Mousa hold US patents on nanoparticulate tetrac (Nanotetrac). The authors report no other conflicts of interest in this work.

\section{References}

1. Goodman AD, Hoekstra SJ, Mars PS. Effects of hypothyroidism on the induction and growth of mammary cancer induced by 7,12-dimethylbenz(a)anthracene in the rat. Cancer Res. 1980;40(7): 2336-2342.

2. Borek C, Guernsey DL, Ong A, Edelman IS. Critical role played by thyroid hormone in induction of neoplastic transformation by chemical carcinogens in tissue culture. Proc Natl Acad Sci U S A. 1983;80(18): $5749-5752$.

3. Hall LC, Salazar EP, Kane SR, Liu N. Effects of thyroid hormones on human breast cancer cell proliferation. J Steroid Biochem Mol Biol. 2008;109(1-2):57-66.

4. Cohen K, Ellis M, Khoury S, Davis PJ, Hercbergs A, Ashur-Fabian O. Thyroid hormone is a MAPK-dependent growth factors for human myeloma cells acting via $\alpha v \beta 3$ integrin. Mol Cancer Res. 2011;9(10): $1385-1394$.

5. Meng R, Tang HY, Westfall J, et al. Crosstalk between integrin $\alpha v \beta 3$ and estrogen receptor- $\alpha$ is involved in thyroid hormone-induced proliferation in human lung cancer cells. PLoS One. 2011; 6(11):e27547.

6. Lin HY, Tang HY, Shih A, et al. Thyroid hormone is a MAPK-dependent growth factor for thyroid cancer cells and is anti-apoptotic. Steroids. 2007;72(2):180-187. 
7. Davis FB, Lin HY, Shih A, et al. Acting via a cell surface receptor, thyroid hormone is a growth factor for glioma cells. Cancer Res. 2006;66(14):7270-7275

8. Davis FB, Mousa SA, O'Connor L, et al. Proangiogenic action of thyroid hormone is fibroblast growth factor-dependent and is initiated at the cell surface. Circ Res. 2004;94(11):1500-1506.

9. Bergh JJ, Lin HY, Lansing L, et al. Integrin alphavbeta3 contains a cell surface receptor for thyroid hormone that is linked to activation of mitogen-activated protein kinase and induction of angiogenesis. Endocrinology. 2005;146(7):2864-2871.

10. Liu X, Zheng N, Shi YN, Yuan J, Li L. Thyroid hormone induced angiogenesis through integrin $\alpha v \beta 3$ /protein kinase $\mathrm{D} /$ histone acetylase 5 signaling pathway. J Mol Endocrinol. 2014;52(3):245-254.

11. Chen J, Ortmeier SB, Savinova OV, et al. Thyroid hormone induces sprouting angiogenesis in adult heart of hypothyroid mice through the PDGF-Akt pathway. J Cell Mol Med. 2012;16(11): 2726-2735.

12. Davis PJ, Davis FB, Mousa SA, Luidens MK, Lin HY. Membrane receptor for thyroid hormone: physiologic and pharmacologic implications. Annu Rev Pharmacol Toxicol. 2011;51:99-115.

13. Luidens MK, Mousa SA, Davis FB, Lin HY, Davis PJ. Thyroid hormone and angiogenesis. Vascul Pharmacol. 2010;52(304):142-145.

14. Hercbergs AA, Goyal LK, Suh JH, et al. Propylthiouracil-induced chemical hypothyroidism with high-dose tamoxifen prolongs survival in recurrent high grade glioma: a Phase I/II trial. Anticancer Res. 2003;23(1B):617-626.

15. Cristofanilli M, Yamamura Y, Kau SW, et al. Thyroid hormone and breast carcinoma. Primary hypothyroidism is associated with a reduced incidence of primary breast carcinoma. Cancer. 2005;103(6): 1122-1128.

16. Schmidinger M, Vogl UM, Bojic M, et al. Hypothyroidism in patients with renal cell carcinoma: blessing or curse? Cancer. 2011;117(3): 534-544.

17. Nelson M, Hercbergs A, Rybicki L, Strome M. Association between development of hypothyroidism and improved survival in patients with head and neck cancer. Arch Otolaryngol Head Neck Surg. 2006;132(10): 1041-1046.

18. Hercbergs AH, Ashur-Fabian O, Garfield D. Thyroid hormones and cancer: clinical studies of hypothyroidism in oncology. Current Opin Endocrinol Diabetes Obes. 2011;17(5):432-436.

19. Plow EF, Haas TA, Zhang L, Loftus J, Smith JW. Ligand binding to integrins. J Biol Chem. 2000;275(29):21785-21788.

20. Lin HY, Lansing L, Merillon JM, et al. Integrin alphavbeta3 contains a receptor site for resveratrol. FASEB J. 2006;20(10):1742-1744.

21. Lin HY, Sun M, Lin C, et al. Androgen-induced human breast cancer cell proliferation is mediated by discrete mechanisms in estrogen receptoralpha-positive and -negative breast cancer cells. J Steroid Biochem Mol Biol. 2009;113(3-5):182-188.

22. Zhou X, Murphy FR, Gehdu N, Zhang J, Iredale JP, Benyon RC. Engagement of alphavbeta3 integrin regulates proliferation and apoptosis of hepatic stellate cells. J Biol Chem. 2004;279(23): 23996-24006.

23. Stefansson S, Su EJ, Ishigami S, et al. The contributions of integrin affinity and integrin-cytoskeletal engagement in endothelial and smooth muscle cell adhesion to vitronectin. J Biol Chem. 2007;282(21):15679-15689.

24. Leonard JL, Farwell AP. Thyroid hormone-regulated actin polymerization in brain. Thyroid. 1997;7(1):147-151.

25. Farwell AP, Dubord-Tomasetti SA, Pietrzykowski AZ, Stachelek SJ, Leonard JL. Regulation of cerebellar neuronal migration and neurite outgrowth by thyroxine and 3,3',5'-triiodothyronine. Brain Res Dev Brain Res. 2005;154(1):121-135.

26. Cohen K, Ellis M, Shindeman E, Khoury S, Davis PJ, Hercbergs A, Ashur-Fabian O. Relevance of thyroid hormones-alphavbeta3 pathway in primary myeloma to bortezomib action. Leuk Lymphoma. 2014;20:1-8.
27. Cheng SY, Leonard JL, Davis PJ. Molecular aspects of thyroid hormone actions. Endocr Rev. 2010;31(2):139-170.

28. Moreno M, De Lange P, Lombardi A, Silvestri E, Lanni A, Goglia F. Metabolic effects of thyroid hormone derivatives. Thyroid. 2008;18(2): 239-253.

29. Lin HY, Cody V, Davis FB, et al. Identification and functions of the plasma membrane receptor for thyroid hormone analogues. Discov Med. 2011;11(59):337-347.

30. Mousa SA, O'Connor L, Davis FB, Davis PJ. Proangiogenesis action of the thyroid hormone analog 3,5-diiodothyropropionic acid (DITPA) is initiated at the cell surface and is integrin-mediated. Endocrinology. 2006;147(4):1602-1607.

31. Lin HY, Sun M, Tang HY, et al. L-thyroxine vs 3,5,3'-triiodo-Lthyronine and cell proliferation: activation of mitogen-activated protein kinase and phosphatidylinositol 3-kinase. Am J Physiol Cell Physiol. 2009;296(5):C980-C991.

32. Mahabeleshwar GH, Feng W, Reddy K, Plow EF, Byzova TV. Mechanisms of integrin-vascular endothelial growth factor receptor crossactivation in angiogenesis. Circ Res. 2007;101(6):570-580.

33. Mousa SA, Bergh JJ, Dier E, et al. Tetraiodothyroacetic acid, a small molecule integrin ligand, blocks angiogenesis induced by vascular endothelial growth factor and basic fibroblast growth factor. Angiogenesis. 2008;11(2):183-190.

34. Mousa SA, Lin HY, Tang HY, Hercbergs A, Luidens MK, Davis PJ. Modulation of angiogenesis by thyroid hormone and hormone analogues: implications for cancer management. Angiogenesis. 2014;17(3):463-469.

35. Yu CH, Law JB, Suryana M, Low HY, Sheetz MP. Early integrin binding to Arg-Gly-Asp peptide activates actin polymerization and contractile movement that stimulates outward translocation. Proc Natl Acad Sci U $S$ A. 2011;108(51):20585-20590.

36. Savinova OV, Liu Y, Aasen GA, et al. Thyroid hormone promotes remodeling of coronary resistance vessels. PLoS One. 2011;6(9):e25054.

37. Glinskii AB, Glinsky GV, Lin HY, et al. Modification of survival pathway gene expression in human breast cancer cells by tetraiodothyroacetic acid (tetrac). Cell Cycle. 2009;8(21):3562-3570.

38. Yalcin M, Dyskin E, Lansing L, et al. Tetraiodothyroacetic acid (tetrac) and nanoparticulate tetrac arrest growth of medullary carcinoma of the thyroid. J Clin Endocrinol Metab. 2010;95(4):1972-1980.

39. Yalcin M, Lin HY, Sudha T, et al. Response of human pancreatic cancer cell xenografts to tetraiodothyroacetic acid nanoparticles. Horm Cancer. 2013;4(3):176-185.

40. Mendelsohn J, Baselga J. Epidermal growth factor receptor targeting in cancer. Semin Oncol. 2006;33(4):369-385.

41. Sarfati M, Fortin G, Raymond M, Susin S. CD47 in the immune response: role of thrombospondin and SIRP-alpha reverse signaling. Curr Drug Targets. 2008;9(10):842-850.

42. Barclay AN, Van den Berg TK. The interaction between signal regulatory protein alpha $(\operatorname{SIRP} \alpha)$ and $\mathrm{CD} 47$ : structure, function, and therapeutic target. Annu Rev Immunol. 2014;32:25-50.

43. Rae MT, Gubbay O, Kostogiannou, Price D, Critchley HO, Hillier SG. Thyroid hormone signaling in human ovarian surface epithelial cells. $J$ Clin Endocrinol Metab. 2007;92(1):322-327.

44. Hadler-Olsen E, Winberg JO, Uhlin-Hansen L. Matrix metalloproteinases in cancer: their value as diagnostic and prognostic markers and therapeutic targets. Tumour Biol. 2013;34(4):2041-2051.

45. Lin HY, Su YF, Hsieh MT, et al. Nuclear monomeric integrin $\alpha \mathrm{v}$ in cancer cells is a coactivator regulated by thyroid hormone. FASEB J. 2013;27(8):3209-3216.

46. Roberts MS, Woods AJ, Dale TC, Van Der Sluijs P, Norman JC. Protein kinase B/Akt acts via glycogen synthase kinase 3 to regulate recycling of alpha v beta 3 and alpha 5 beta 1 integrins. Mol Cell Biol. 2004;24(4):1505-1515.

47. Hercbergs A, Davis PJ, Davis FB, Ciesielski MJ, Leith JT. Radiosensitization of GL261 glioma cells by tetraiodothyroacetic acid (tetrac). Cell Cycle. 2009;8(16):2586-2591. 
48. Hercbergs AH, Lin HY, Davis FB, Davis PJ, Leith JT. Radiosensitization and production of DNA double-strand breaks in U87MG brain tumor cells induced by tetraiodothyroacetic acid (tetrac). Cell Cycle. 2011;10(2):352-357.

49. Mousa SA, Thangirala S, Yalcin M, et al. Actions of nanoparticulate tetraiodothyroacetic acid (Nanotetrac) on human prostate carcinoma xenograft growth, vascularity and integrin response to radiation. Annual Meeting of the American Association for Cancer Research; April 9, 2014; San Diego, CA, USA. Abstract 5378.

50. Shih A, Lin HY, Davis FB, Davis PJ. Thyroid hormone promotes serine phosphorylation of 553 by mitogen-activated protein kinase. Biochemistry. 2001;40(9):2870-2878.
51. Shih A, Zhang S, Cao HJ, et al. Disparate effects of thyroid hormone on actions of epidermal growth factor and transforming growth factor- $\alpha$ are mediated by $3^{\prime}, 5^{\prime}$-cyclic adenosine 5'-monophosphatedependent protein kinase II. Endocrinology. 2004;145(4):1708-1717.

52. Bharali DJ, Yalcin M, Davis PJ, Mousa SA. Tetraiodothyroacetic acid-conjugated PLGA nanoparticles: a nanomedicine approach to treat drug-resistant breast cancer. Nanomedicine (Lond). 2013;8(12): 1943-1954.

\section{Publish your work in this journal}

OncoTargets and Therapy is an international, peer-reviewed, open access journal focusing on the pathological basis of all cancers, potential targets for therapy and treatment protocols employed to improve the management of cancer patients. The journal also focuses on the impact of management programs and new therapeutic agents and protocols on

\section{Dovepress}

patient perspectives such as quality of life, adherence and satisfaction. The manuscript management system is completely online and includes a very quick and fair peer-review system, which is all easy to use. Visit http://www.dovepress.com/testimonials.php to read real quotes from published authors. 